\title{
Generation of the Bovine Viral Diarrhea Virus E0 Protein in Transgenic Astragalus and Its Immunogenicity in Sika Deer
}

\author{
Yugang Gao, Xueliang Zhao, Pu Zang, Qun Liu, Gongqing Wei, and Lianxue Zhang \\ College of Traditional Material Medicine, Jilin Agricultural University, Changchun 130118, China \\ Correspondence should be addressed to Lianxue Zhang; lianxuezhang863@sina.com
}

Received 24 March 2014; Revised 29 April 2014; Accepted 6 May 2014; Published 22 May 2014

Academic Editor: Shi-Biao Wu

Copyright (c) 2014 Yugang Gao et al. This is an open access article distributed under the Creative Commons Attribution License, which permits unrestricted use, distribution, and reproduction in any medium, provided the original work is properly cited.

\begin{abstract}
The bovine viral diarrhea virus (BVDV), a single-stranded RNA virus, can cause fatal diarrhea syndrome, respiratory problems, and reproductive disorders in herds. Over the past few years, it has become clear that the BVDV infection rates are increasing and it is likely that an effective vaccine for BVDV will be needed. In this study, transgenic Astragalus was used as an alternative productive platform for the expression of glycoprotein E0. The immunogenicity of glycoprotein E0 expressed in transgenic Astragalus was detected in deer. The presence of $\mathrm{pBI} 121-\mathrm{E} 0$ was confirmed by polymerase chain reaction (PCR), transcription was verified by reverse transcription- (RT-) PCR, and recombinant protein expression was confirmed by ELISA and Western blot analyses. Deer that were immunized subcutaneously with the transgenic plant vaccine developed specific humoral and cell-mediated immune responses against BVDV. This study provides a new method for a protein with weak immunogenicity to be used as part of a transgenic plant vaccine.
\end{abstract}

\section{Introduction}

Bovine viral diarrhea (BVD) is a widespread disease that affects cattle [1]. The causative agent is the bovine viral diarrhea virus (BVDV), a Pestivirus of the family Flaviviridae. BVDV infection presents a wide spectrum of diseases, ranging from mild acute infection to fatal mucosal disease [2]. The virus is known to damage the immune system of the infected animals, which can make the animals more susceptible to other diseases and causes significant loss to the livestock industry [3-5]. The virus can infect and be transmitted between a variety of animals, such as cattle, sheep, and whitetail deer [6-9]. In our previous study, a new single strain of BVDV named CCSYD was isolated and verified from sika deer [10].

Different strategies are available to control the spread of BVDV in a herd, such as vaccination and test-andcull schemes. Among these strategies, test-and-cull schemes have been very successfully applied in areas with low cattle densities and low BVDV prevalence, such as Scandinavia [11, 12]. But in the areas with high cattle densities and high BVDV prevalence, the program will bring huge economic loss. Vaccine research is considered to be a promising alternative to prevent BVDV spread. Inactivated vaccines generally possess inadequate efficacy and do not induce sufficient protective immunity. Although modified live vaccines provide certain protection against homologous strains, the intrinsic risk of virulence reversion remains a concern $[13,14]$. Due to the poor immunogenicity of inactivated vaccines and the safety concerns surrounding the use of modified live vaccine, an effective subunit vaccine for BVDV has become the subject of increasing research interest [15].

BVDV is a single-stranded RNA virus and has approximately $12.5 \mathrm{~kb}$ RNA genome [16] and the genomes of BVDV are translated and processed into eleven mature proteins. After infection or vaccination, cattle elicit antibodies to the three envelope proteins E0, E1, and E2 and against the nonstructural protein $\mathrm{NS}_{3}$ [17]. Glycoprotein E2 is the major target of the protective immune response triggered against BVDV infection and is widely used for subunit vaccines $[18,19]$. However, the highly variable sequence of E2 protein often leads to immune failure [20,21]. 
E0 is a conserved protein and shows less antigenic diversity than E2 [22]. Nevertheless, the BVDV E0 expressed in prokaryotes system produced neutralizing antibodies but at low titers that could not efficiently neutralize virus, which was attributed to a misfolding of E0 [17]. In view that eukaryotic expression could maintain the correct folding and glycosylation of proteins, eukaryotic expression has become the research focus in the study of subunit vaccine. Last year, Gao et al. [23] successfully constructed a prokaryotic expression vector PVAX1-E0 and identified its antigen activity in rabbits. The result shows that the recombined PVAX1-E0 could produce specific humoral and cellular immune response in rabbits. Transgenic plants are new eukaryotic expressiondelivery systems that have become attractive bioreactors in the production of high-value medical peptides and proteins [24]. Up to now, several types of plant species have been used as antigen-delivery systems for subunit vaccines $[25,26]$. For example, the truncated glycoprotein BVDV E2 has been expressed in N. tabacum leaves and subsequently showed high reactivity in virus neutralization test [27].

Another strategy to improve the immune activity of vaccine is the use of adjuvant [28]. Vaccine adjuvant can stimulate the immune system to an increased specific antibody response. Radix Astragali (Astragalus) is a plant used as a traditional herb medicine in China, and it is known for its antiviral activity and immunity-boosting properties [29-31]. Astragalus polysaccharides can improve the function of macrophages, enhance macrophage phagocytosis, and increase the activity of natural killer (NK) cells [32]. Astragalus as host plants can play a role in the immune adjuvant to enhance the immune level.

In this study, plant expression vector pBI121-E0 was constructed and transferred into Astragalus. The immunogenicity and protective efficacy of the recombinant proteins were demonstrated in deer. The aim of this study was to develop a transgenic Astragalus vaccine for bovine viral diarrhea.

\section{Materials and Methods}

2.1. Reagents, Bacteria, and Plasmids. The plasmid pMD18T-E0 was developed in our previous work [23]. The E. coli strain $\mathrm{DH} 5 \alpha$ was purchased from Invitrogen (Shanghai, China). Plasmid pBI121 (Novagen, Darmstadt, Germany) was used for recombinant protein expression. Restriction enzymes, Taq DNA polymerase, TriPure Kit, and T4 ligase were purchased from TaKaRa Biotechnology Co., Dalian, China.

2.2. Plasmid Construction. The BVDV E0 open reading frame was amplified from plasmid pMD18-T-E0 which contains the complete gene with the forward primer $\left(5^{\prime}\right.$-CCG GAT CCA CCA TGG AAA ACA TAA CAC AGT GG-3', BamHI site underlined) and the reverse primer $\left(5^{\prime}\right.$-GCG AGC TCT TAA GCG TAT GCT CCA AAC CAC GT- $3^{\prime}$, SacI site underlined). The PCR product was digested with BamHI and SacI and inserted into plant expression vector $\mathrm{pBI} 121$ digested with the same enzymes to create the recombinant plasmid pBI121-E0.
2.3. Plant Transformation and Genetic Analysis. The Astragalus membranaceus (Fisch.) Bungevar. mongholicus (Bunge) P. K. Hsiao cultivated in our laboratory was used as the host plant. The transformation experiment was carried out in the middle of July. After $20 \mathrm{~h}$ artificial pollination [33], $150 \mu \mathrm{L}$ plasmid pBI121-E0 (1-2 ng/ $\mu \mathrm{L})$ was applied to the stigmas evenly using a micropipette. At maturity stage, seeds were harvested and stored at room temperature. The transgenic seedlings were identified by PCR and RT-PCR analysis with the forward primer $5^{\prime}$-CCG GAT CCA CCA TGG AAA ACA TAA CAC AGT GG-3 $3^{\prime}$ and the reverse primer $5^{\prime}$-GCG AGC TCT TAA GCG TAT GCT CCA AAC CAC GT- $3^{\prime}$.

2.4. Protein Extraction. Protein isolation was conducted using $0.5 \mathrm{~g}$ fresh leaves of regeneration seedlings that were quickly ground in liquid nitrogen. The resulting powder was resuspended in $1 \mathrm{~mL}$ extraction buffer $\left(0.24 \mathrm{~g} / \mathrm{L} \mathrm{KH}_{2} \mathrm{PO}_{4}\right.$, $1.44 \mathrm{~g} / \mathrm{L} \mathrm{Na} \mathrm{HPO}_{4}, 0.2 \mathrm{~g} / \mathrm{L} \mathrm{KCl}, 8 \mathrm{~g} / \mathrm{L} \mathrm{NaCl}, 10 \mu \mathrm{g} / \mathrm{mL}$ leupeptin, $5 \mathrm{mM}$ PMSF, $50 \mathrm{mM}$ EDTA, and $\mathrm{pH} 7.0-7.2$ ) as previously described [27]. The mixture was centrifuged at $12,000 \mathrm{~g}$ for $20 \mathrm{~min}$ at $4^{\circ} \mathrm{C}$, and the protein concentration was measured by the Bradford protein assay [34] in $1 \mathrm{~mL}$ of the supernatant using bovine serum albumin (BSA) as a standard.

2.5. Enzyme-Linked Immunosorbent Assay (ELISA). To illustrate the expression of glycoprotein E0, the ELISA was carried out. ELISA assay plates were coated at $4^{\circ} \mathrm{C}$ overnight with $90 \mu \mathrm{L}$ protein samples (containing $30 \mu \mathrm{g}$ total protein extracted from transgenic Astragalus) diluted in $10 \mu \mathrm{L}$ coating buffer ( $\mathrm{pH}=8.0$ ). After removing the liquid, the plates were washed three times with phosphate-buffered saline (PBS) with Tween 20 (PBST) and blocked with $10 \%$ horse serum at $37^{\circ} \mathrm{C}$ for $1 \mathrm{~h}$. Then, BVDV-positive bovine serum $(1: 20$ dilution) was added to the plates and incubated for $1 \mathrm{~h}$ at $37^{\circ} \mathrm{C}$. Then, the plates were incubated for $1 \mathrm{~h}$ at $37^{\circ} \mathrm{C}$ with horseradish peroxidase (HRP) conjugated rabbit anti-bovine $\operatorname{IgG}(1: 5,000$ dilution) as the secondary antibody. Substrate was added for colour reaction at $37^{\circ} \mathrm{C}$ for $15 \mathrm{~min}$ and reaction was terminated by adding $2 \mathrm{M} \mathrm{H}_{2} \mathrm{SO}_{4}(50 \mu \mathrm{L} /$ well $)$. The absorbance was examined using an ELISA reader at $490 \mathrm{~nm}$.

2.6. Western Blot Analysis. To further demonstrate the immune activity of the glycoprotein E0 expressed in transgenic lines, the recombinant proteins were detected by Western blot analysis. The total soluble proteins $(60 \mu \mathrm{g})$ extracted from fresh leaves of transgenic Astragalus were subjected to electrophoresis on a $12 \%$ sodium dodecyl sulfate polyacrylamide gel (SDS-PAGE) and transferred to a nitrocellulose membrane (GE Healthcare, USA). Western blot was carried out using BVDV-positive bovine serum (1:100 dilution) and HRP-conjugated rabbit anti-bovine IgG (1:5000 dilution, Southern Biotechnology, USA) as the primary and secondary antibodies, respectively. The total proteins were extracted from wild-type Astragalus as negative control and glycoprotein E0 was expressed in the baby hamster kidney- (BHK-) 21 cells [23] as a positive control. 
2.7. Ethics Statement. All the deer were obtained from DongDa Deer Industry Co., Ltd. The deer care and maintenance at the sika deer farm of Jilin Agricultural University and permission to undertake this work were granted by the Management Bureau of Animal Husbandry in Jilin Province (Shaoxian Liu, Director). The research was also approved by the animal ethics committees of Jilin Agricultural University and the National Deer Industry Association of China Animal Agriculture Association (CAAA). We anesthetized all deer prior to sampling. The blood samplings were performed by veterinarians, biologists, or technicians with previous training and experience in these procedures. We collected up to $2 \mathrm{~mL}$ of blood via the jugular vein. All surgery was performed under sodium pentobarbital and all efforts were made to minimize suffering. Finally, all the deer were not sacrificed.

2.8. Immunization Schedule. Thirty healthy one-month-old young male sika deer were randomly divided into five groups (six deer per group). The vaccines were prepared as previously described [27]. Briefly, montanide ISA 70 SEPPIC and Al $(\mathrm{OH})_{3}$ hydrogel were used as the adjuvant in oil vaccine and in aqueous vaccine. And the ratios of antigen to adjuvant were 40:60 and 90:10, respectively. The deer in group one were immunized subcutaneously with $1 \mathrm{~mL}$ formulated oil vaccine containing $100 \mu \mathrm{g}$ total protein extracted from transgenic Astragalus; group two was immunized s.c. with $1 \mathrm{~mL}$ formulated aqueous vaccine containing the same dose of the protein extracted from transgenic Astragalus. Group three and group four acted as negative groups; deer in the two groups were immunized s.c. with $1 \mathrm{~mL}$ oil vaccine and aqueous vaccine containing $100 \mu \mathrm{g}$ total protein extracted from wild-type Astragalus, respectively. Group five was injected s.c. with $100 \mathrm{TCID}_{50}$ of inactivated BVDV vaccine (purchased from Chinese Veterinary Drug Control Room). The second immunization was carried out in all groups on day 14. Blood samples were collected at the time of immunization (day 0 ) and on the days $7,14,21,28,35$, and 42 after the first immunization. The blood sera were used for lymphocyte blastogenesis assay and ELISA assay.

\subsection{Determination of Specific Antibodies in Immunized Deer.} The blood taken from sika deer was diluted (1:40) with coating buffer $(\mathrm{pH}=8.0)$ and added into microtiter plates $(100 \mu \mathrm{L} /$ well). The microtiter plates were coated for $2 \mathrm{~h}$ at $37^{\circ} \mathrm{C}$. After removing the liquid, the plates were washed three times with PBST and blocked with $10 \%$ horse serum for $2 \mathrm{~h}$ at $37^{\circ} \mathrm{C}$. Then, $100 \mu \mathrm{L}$ soluble whole virus antigen (containing $100 \mu \mathrm{g}$ viral proteins) extracted from the $\mathrm{C}_{24} \mathrm{~V}$ BVDV (purchased from the China Institute of Veterinary Drug Control) was added to the plates and incubated for $2 \mathrm{~h}$ at $37^{\circ} \mathrm{C}$. The plates were then washed three times with PBST and incubated for $1 \mathrm{~h}$ at $37^{\circ} \mathrm{C}$ with $100 \mu \mathrm{L}$ BVDV-positive bovine serum (1:200 dilution). HRP-conjugated rabbit anti-bovine IgG (1:5000 dilution) was used as the secondary antibody. Substrate was added to facilitate the color reaction at $37^{\circ} \mathrm{C}$ for $15 \mathrm{~min}$ and the reaction was terminated by the addition of $2 \mathrm{M}$ $\mathrm{H}_{2} \mathrm{SO}_{4}(50 \mu \mathrm{L} /$ well $)$. The optical density (OD) was assessed at $490 \mathrm{~nm}$.
2.10. Lymphocyte Blastogenesis Assay. Peripheral blood mononuclear cells were isolated from anticoagulated jugular blood as previously reported (see Figure 4) [35]. More than $95 \%$ of the cells were lymphocytes. The cell viability was checked with a trypan blue dye exclusion assay and the cells were resuspended in Roswell Park Memorial Institute medium (RPMI) 1640, supplemented with 10\% fetal bovine serum, $100 \mathrm{IU} / \mathrm{mL}$ penicillin (Sigma), and $100 \mathrm{mg} / \mathrm{mL}$ streptomycin (Sigma). The cells were placed into 96-well roundbottom plates at a concentration of $4 \times 10^{6}$ cells/well $(100 \mu \mathrm{L})$ and incubated with or without BVDV $\left(10^{4}\right.$ TCID50/well) in hexaplicate at $37^{\circ} \mathrm{C}$ under $5 \% \mathrm{CO}_{2}$. Phytohaemagglutinin(PHA) (Sigma) at $5 \mathrm{mg} / \mathrm{mL}$ was used as a positive control. After 40 to $48 \mathrm{~h}$ incubation at $37^{\circ} \mathrm{C}$ under $5 \% \mathrm{CO}_{2}, 3-$ (4,5-dimethylthiazol-2-yl)-2, 5-diphenyltetrazolium bromide (MTT) was added to each well and the cells were cultured for $4 \mathrm{~h}$. After the addition of $100 \mu \mathrm{L}$ dimethyl sulfoxide (DMSO) to each well to stop the colour development, plates were tested at $570 \mathrm{~nm}$.

2.11. Statistical Analysis. Multiple group comparisons were performed using one way analysis of variance (ANOVA) followed by Tukey's test in order to detect intergroup differences. GraphPad Prism software (Version 5.0; GraphPad Software, Inc., San Diego, CA) was used to perform the statistical analysis. A value of $P<0.05$ was considered statistically significant.

\section{Results}

3.1. Genetic Identification of the Transgenic Astragalus. To confirm the integration of the E0 gene into the chromosome of transgenic seedlings, genomic DNA and total RNA were isolated from transgenic Astragalus and tested by PCR and RT-PCR. As expected, specific bonds of 706 bp were detected in all groups except for the negative control groups (Figures 1(a) and 1(b)).

3.2. Expression of E0 Protein in Transgenic Astragalus Seedlings. The ELISA assay was used to determine the expression of glycoprotein E0 in transgenic Astragalus. The OD490 values of transgenic Astragalus groups were similar to the positive groups but significantly higher than the negative groups (Figure 2(a)). That reveals glycoprotein E0 was highly expressed in transgenic Astragalus. To further confirm the immune activity of E0 protein, the Western blot analysis was carried out. A specific band of $50 \mathrm{kDa}$ corresponding to glycoprotein E0 was detected in coomassie blue gel analysis (Figure 2(b)) and Western blot for both the samples and the positive control was shown in Figure 2(c). As expected, it was not detected in the negative controls.

3.3. Detection of Deer Serum Antibody and Cellular Immune Level. The serum antibody levels of immune deer were detected by ELISA and the results are shown in Figure 3. Before immunization, no significant difference was found among all groups. But, in the serum of immunized deer for the first seven days, the serum antibodies in oil vaccine 


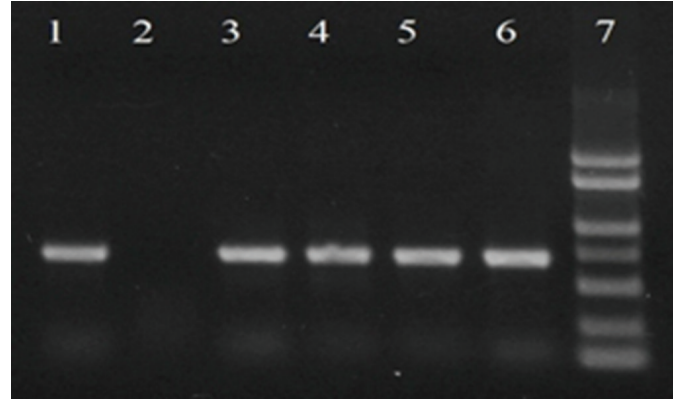

(a)

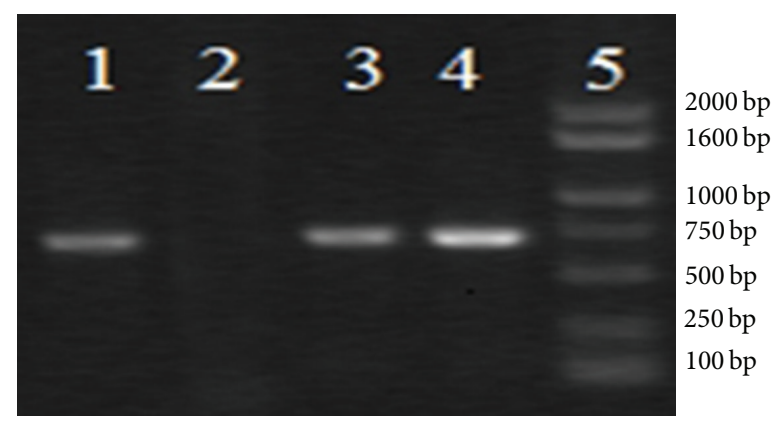

(b)

FIgURE 1: Genetic identification of the transgenic Astragalus. The genomic DNA and total RNA were extracted from the leaves of transgenic Astragalus for PCR (a) and RT-PCR (b) identification, respectively. (a) PCR analysis of the transgenic Astragalus. Total genomic DNAs were extracted from the leaves of different transgenic Astragalus spp. (lanes 3-6) and untransformed wild-type Astragalus (lane 2 as negative control). Lane 1 is indicated as the positive control by using pBI121-E0 plasmid DNA as PCR template. The left showed the DNA molecular mass marker (lane 5); (b) RT-PCR analysis. DNA fragment was amplified from the transformed plant with E0 specific primers. Lane 1: PCR product from the plasmid pBI121-E0. Lane 2: RT-PCR product from nontransformed Astragalus. Lanes 3-4: RT-PCR product from different transgenic Astragalus spp. Lane 5 showed the DNA molecular mass marker.

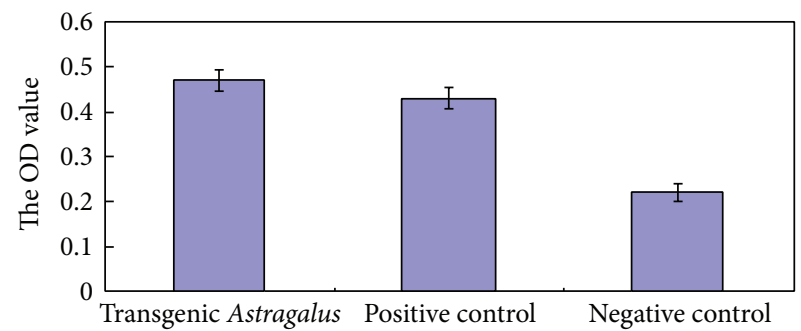

(a)

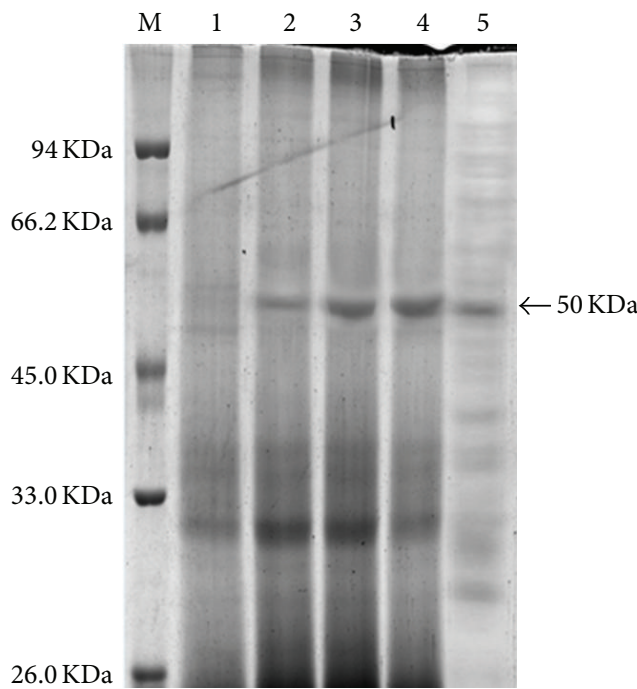

(b)

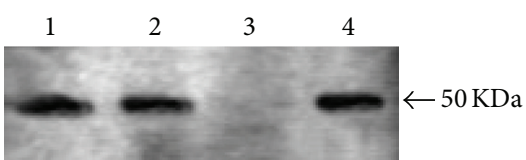

(c)

FIgURE 2: Protein analysis in transgenic Astragalus extract. (a) ELISA test to determine the presence of the antigen E0 in transgenic Astragalus leaves extract. ELISA protocol was described in methods section. Transgenic Astragalus group (the recombinant proteins extracted from transgenic Astragalus leaves); positive control (E0 protein expressed in BHK-21 cells); negative control (proteins extracted from wild-type Astragalus). (b) Coomassie brilliant blue staining of protein extracted from transgenic Astragalus leaves analyzed by $12 \%$ of SDS-PAGE. M: protein markers, 1: negative control, 2-4: transgenic Astragalus groups, 5: positive control. (c) Western blot analysis showing immune activity of the E0 protein expressing in transgenic Astragalus. In transgenic Astragalus group (lanes 1, 4) and positive control (lane 2 E0 protein expressed in BHK-21 cells) a specific band of $50 \mathrm{kDa}$ was detected. Lane 3: negative control (proteins extracted from wild-type Astragalus).

group, aqueous vaccine group, and inactivated BVDV vaccine group were significantly higher than negative groups $(P<$ $0.05)$. The antibody levels increased with the immune time in all groups, except for negative groups. With the increasing of the immune time, the antibody levels of deer BVDV inactivated vaccine group reached the peak value after 35 days of immunization, while oil vaccine group and aqueous vaccine group reached the peak value after 42 days. This revealed that oil vaccine and aqueous vaccine gave the deer longer protection from BVDV infection. 


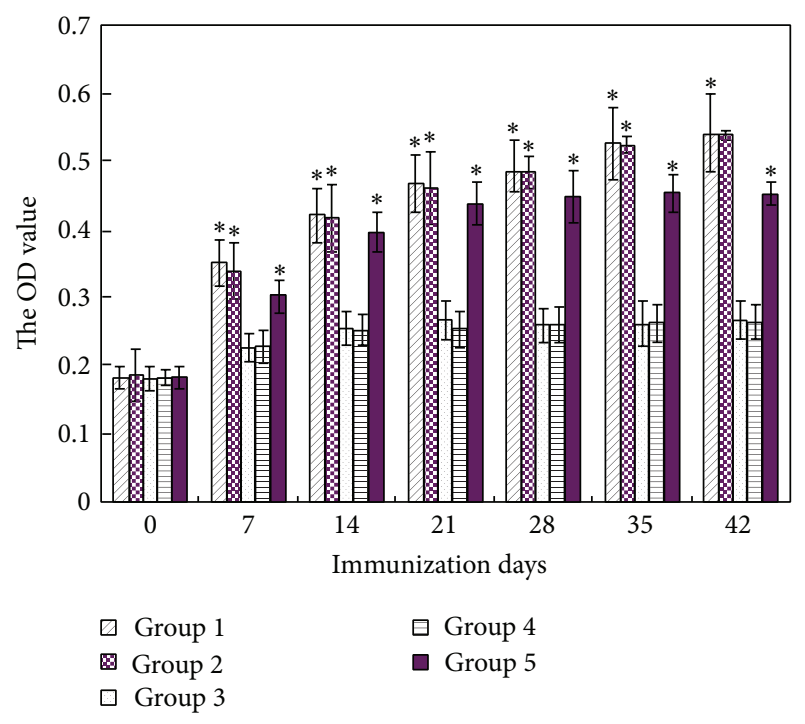

FIGURE 3: Specific humoral response in deer following vaccination. The deer were immunized subcutaneously with transgenic Astragalus oil vaccine (group 1), transgenic Astragalus aqueous vaccine (group 2), oil negative control (group 3), aqueous negative control (group 4), and inactivated BVDV vaccine (group 5). Serum samples used to assess the humoral immune response were collected on days $0,7,14,21,28,35$, and 42 after primary immunization and detected at $490 \mathrm{~nm} .{ }^{*}$ The difference between aqueous negative control (group 4 ) and other groups at the same days after primary immunization is significant $(P<0.05)$.

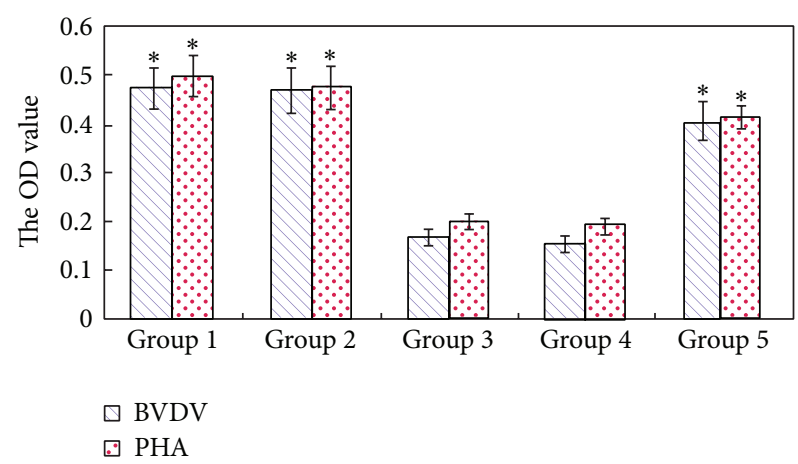

FIGURE 4: Lymphocyte blastogenesis assay. The blood was collected from each deer on day 42 after the immunization. Group 1: transgenic Astragalus oil vaccine; group 2: transgenic Astragalus aqueous vaccine; group 3: oil negative control; group 4: aqueous negative control; group 5: inactivated BVDV vaccine. ${ }^{*}$ The difference between aqueous negative control (Group 4) and other groups is significant $(P<0.05)$.

To evaluate the cell-mediated immune responses, blood samples were collected on the 42 nd day after immunization and tested for lymphocyte proliferative responses. As shown in Figure 3, the results indicated that lymphocytes present in blood from deer that received transgenic Astragalus plants proliferated substantially upon restimulation with BVDV antigens (Figure 3). This specific proliferation was absent in the negative groups that received nontransformed leaves (Figure 3). The result is corresponding to the result of PHA-induced lymphocyte proliferation. This suggested that BVDV-E0 specific prolonged cell-mediated immune responses in deer subcutaneously immunized with E0 transgenic Astragalus plant leaves were present.

\section{Discussion}

BVDV infection is an important cause of morbidity and economical losses in cattle worldwide. It is estimated that BVD generates a negative economic impact in dairy operations (between $\$ 20$ and $\$ 160$ per adult cow per year) [36]. Developing effective and inexpensive vaccines is critical for protecting animals against BVDV infection. With the development of genetic molecular biology and plant biotechnology, plants have emerged as a new platform for the production and delivery of antigenic proteins as plant-based vaccines. Plant-based vaccines offer several advantages over traditional vaccine such as ease of delivery, mucosal efficacy, safety, rapid scalability, and low cost. However, there are still no reports about the expression of E0 glycoprotein in plants. This experiment successfully acquired glycoprotein E0 of BVDV in transgenic Astragalus through pollen-tube pathway. This is the first report on the expression of E0 glycoprotein in a medicinal plant.

The glycoprotein E0 has several functions, such as virus attachment and entry to target cells and the production of neutralizing antibodies, as well as having effects on the pathogenicity of BVDV $[37,38]$. The glycoprotein E0 consists of 227 amino acids and isoelectric point is 7.61 [39]. As a conserved protein, E0 shows less antigenic diversity than E2. However, as antigen for BVDV, E0 still has many defects. For example, E0 has many glycosylation sites that are important for proper folding and activity maintenance of protein, and it also exhibits weak immunogenicity. In this study, the transgenic Astragalus was successfully used as a platform for production of the glycoprotein E0, which allowed us to overcome the above shortcomings. Astragalus extracted as vaccine adjuvant significantly improves immune activity of E0 subunit vaccine. As such, the plant-made glycoprotein E0 has the ability to generate an immune response in sika deer. This study provides a new method for proteins with weak immunogenicity to be used as transgenic vaccine candidates by use of a plant system.

The use of transgenic plants as new antigen-delivery systems for subunit vaccines has been increasingly explored [40]. Astragalus has immunomodulatory effects and Astragalus as host plants can play a role in the immune adjuvant to enhance the immune level. Plants can be mass-produced, inexpensive source of antigens, and an ideal system for subunit vaccine. The research provided new ideas for the development of transgenic medicinal plants vaccines.

\section{Conclusions}

In summary, glycoprotein E0 was effectively expressed in transgenic Astragalus. Deer immunized subcutaneously 
(s.c.) with the transgenic plant vaccine could develop specific humoral and cell-mediated immune responses against BVDV. The research provides new ideas for the development of medicinal plants vaccine.

\section{Conflict of Interests}

The authors declare that there is no conflict of interests regarding the publication of this paper.

\section{Authors' Contribution}

Yugang Gao and Xueliang Zhao contributed equally to this work.

\section{Acknowledgments}

The authors gratefully acknowledge the financial support provided by the National Natural Science Foundation of China (31070316), Ministry of Science and Technology of China (2011BAT03B01), and Science and Technology Department of Jilin Province (2010B10010945, 20110228, and 20112101).

\section{References}

[1] G. J. Gunn, H. W. Saatkamp, R. W. Humphry, and A. W. Stott, "Assessing economic and social pressure for the control of bovine viral diarrhoea virus," Preventive Veterinary Medicine, vol. 72, no. 1-2, pp. 149-162, 2005.

[2] W. Z. Xue, D. Mattick, L. Smith, J. Umbaugh, and E. Trigo, "Vaccination with a modified-live bovine viral diarrhea virus (BVDV) type la vaccine completely protected calves against challenge with BVDV type $1 \mathrm{~b}$ strains," Vaccine, vol. 29, no. 1, pp. 70-76, 2010.

[3] M. Al-Haddawi, G. B. Mitchell, M. E. Clark, R. D. Wood, and J. L. Caswell, "Impairment of innate immune responses of airway epithelium by infection with bovine viral diarrhea virus," Veterinary Immunology and Immunopathology, vol. 116, no. 3-4, pp. 153-162, 2007.

[4] I. M. G. A. Berends, W. A. J. M. Swart, K. Frankena, J. Muskens, T. J. G. M. Lam, and G. van Schaik, "The effect of becoming BVDV-free on fertility and udder health in Dutch dairy herds," Preventive Veterinary Medicine, vol. 84, no. 1-2, pp. 48-60, 2008.

[5] E. Peterhans, T. W. Jungi, and M. Schweizer, "How the bovine viral diarrhea virus outwits the immune system," Deutsche Tierarztliche Wochenschrift, vol. 113, no. 4, pp. 124-129, 2006.

[6] H. Yilmaz, E. Altan, J. Ridpath, and N. Turan, "Genetic diversity and frequency of bovine viral diarrhea virus (BVDV) detected in cattle in Turkey," Comparative Immunology, Microbiology and Infectious Diseases, vol. 35, no. 5, pp. 411-416, 2012.

[7] T. Passler, P. H. Walz, S. S. Ditchkoff, M. D. Givens, H. S. Maxwell, and K. V. Brock, "Experimental persistent infection with bovine viral diarrhea virus in white-tailed deer," Veterinary Microbiology, vol. 122, no. 3-4, pp. 350-356, 2007.

[8] S. Juliá, M. I. Craig, L. S. Jiménez, G. B. Pinto, and E. L. Weber, "First report of BVDV circulation in sheep in Argentina," Preventive Veterinary Medicine, vol. 90, no. 3-4, pp. 274-277, 2009.

[9] T. Passler, P. H. Walz, S. S. Ditchkoff et al., "Cohabitation of pregnant white-tailed deer and cattle persistently infected with Bovine viral diarrhea virus results in persistently infected fawns," Veterinary Microbiology, vol. 134, no. 3-4, pp. 362-367, 2009.

[10] Y. G. Gao, S. J. Wang, R. Du et al., "Isolation and identification of a bovine viral diarrhea virus from sika deer in China," Virology Journal, vol. 8, article 83, 2011.

[11] I. Greiser-Wilke, B. Grummer, and V. Moennig, "Bovine viral diarrhoea eradication and control programmes in Europe," Biologicals, vol. 31, no. 2, pp. 113-118, 2003.

[12] A.-F. Viet, C. Fourichon, and H. Seegers, "Simulation study to assess the efficiency of a test-and-cull scheme to control the spread of the bovine viral-diarrhoea virus in a dairy herd," Preventive Veterinary Medicine, vol. 76, no. 3-4, pp. 151-166, 2006.

[13] R. W. Fulton, J. F. Ridpath, A. W. Confer, J. T. Saliki, L. J. Burge, and M. E. Payton, "Bovine viral diarrhoea virus antigenic diversity: impact on disease and vaccination programmes," Biologicals, vol. 31, no. 2, pp. 89-95, 2003.

[14] C. L. Kelling, "Evolution of bovine viral diarrhea virus vaccines," Veterinary Clinics of North America-Food Animal Practice, vol. 20, no. 1, pp. 115-129, 2004.

[15] C. Thomas, N. J. Young, J. Heaney, M. E. Collins, and J. Brownlie, "Evaluation of efficacy of mammalian and baculovirus expressed E2 subunit vaccine candidates to bovine viral diarrhoea virus," Vaccine, vol. 27, no. 17, pp. 2387-2393, 2009.

[16] M. Schweizer, P. Mätzener, G. Pfaffen, H. Stalder, and E. Peterhans, "'Self" and "nonself" manipulation of interferon defense during persistent infection: bovine viral diarrhea virus resists alpha/beta interferon without blocking antiviral activity against unrelated viruses replicating in its host cells," Journal of Virology, vol. 80, no. 14, pp. 6926-6935, 2006.

[17] S. R. Bolin, "Immunogens of bovine viral diarrhea virus," Veterinary Microbiology, vol. 37, no. 3-4, pp. 263-271, 1993.

[18] P. Andrea, S. A. María, A. Alejandra et al., "Safety and efficacy of an E2 glycoprotein subunit vaccine produced in mammalian cells to prevent experimental infection with bovine viral diarrhoea virus in cattle," Veterinary Research Communications, vol. 36, no. 3, pp. 157-164, 2012.

[19] M. K. Baxi, D. Deregt, J. Robertson, L. A. Babiuk, T. Schlapp, and S. K. Tikoo, "Recombinant bovine adenovirus type 3 expressing bovine viral diarrhea virus glycoprotein E2 induces an immune response in cotton rats," Virology, vol. 278, no. 1, pp. 234-243, 2000.

[20] T. Rümenapf, G. Unger, J. H. Strauss, and H.-J. Thiel, "Processing of the envelope glycoproteins of pestiviruses," Journal of Virology, vol. 67, no. 6, pp. 3288-3294, 1993.

[21] W. Xue, F. Blecha, and H. C. Minocha, "Antigenic variations in bovine viral diarrhea viruses detected by monoclonal antibodies," Journal of Clinical Microbiology, vol. 28, no. 8, pp. 1688$1693,1990$.

[22] R. W. Fulton, D. L. Step, J. F. Ridpath et al., "Response of calves persistently infected with noncytopathic bovine viral diarrhea virus (BVDV) subtype $1 \mathrm{~b}$ after vaccination with heterologous BVDV strains in modified live virus vaccines and Mannheimia haemolytica bacterin-toxoid," Vaccine, vol. 21, no. 21-22, pp. 2980-2985, 2003.

[23] Y. G. Gao, Y. J. Wang, R. Du et al., "A recombinant E0 gene of bovine viral diarrhea virus protects against challenge with bovine viral diarrhea virus of sika deer," African Journal of Microbiology Research, vol. 5, no. 9, pp. 1012-1017, 2011.

[24] Z.-Q. Yang, Q.-Q. Liu, Z.-M. Pan, H.-X. Yu, and X.-A. Jiao, "Expression of the fusion glycoprotein of newcasstle disease 
virus in transgenic rice and its immunogenicity in mice," Vaccine, vol. 25, no. 4, pp. 591-598, 2007.

[25] H.-F. Chen, M.-H. Chang, B.-L. Chiang, and S.-T. Jeng, "Oral immunization of mice using transgenic tomato fruit expressing VP1 protein from enterovirus 71," Vaccine, vol. 24, no. 15, pp. 2944-2951, 2006.

[26] Z.-J. Guan, B. Guo, Y.-L. Huo, Z.-P. Guan, and Y.-H. Wei, "Overview of expression of hepatitis B surface antigen in transgenic plants," Vaccine, vol. 28, no. 46, pp. 7351-7362, 2010.

[27] G. Nelson, P. Marconi, O. Periolo, J. L. Torre, and M. A. Alvarez, "Immunocompetent truncated E2 glycoprotein of bovine viral diarrhea virus (BVDV) expressed in Nicotiana tabacum plants: a candidate antigen for new generation of veterinary vaccines," Vaccine, vol. 30, no. 30, pp. 4499-4504, 2012.

[28] V. E. J. C. Schijns and E. C. Lavelle, "Trends in vaccine adjuvants," Expert Review of Vaccines, vol. 10, no. 4, pp. 539-550, 2011.

[29] Y. U. Ling, J. Z. Li, and H. Y. Wang, "Progress in the study of the treatment of nephropathy with Astragalus and Angelica and their therapeutic mechanism," Chinese Journal of Integrated Traditional and Western Medicine, vol. 21, no. 5, pp. 396-399, 2001.

[30] L. Y. Qi and H. X. li, "The study of chemical composition and pharmacological function on Astragalus," Journal of Baoding Teachers College, vol. 17, no. 4, pp. 40-42, 2004.

[31] W. Zhao, Y.-F. Ren, and J.-H. Fan, "Study on effects of Astragalus aksuensis against virus," Chinese Pharmaceutical Journal, vol. 36, no. 1, pp. 23-25, 2001.

[32] S. L. Yuan, X. S. Piao, D. F. Li, S. W. Kim, H. S. Lee, and P. F. Quo, "Effects of dietary Astragalus polysaccharide on growth performance and immune function in weaned pigs," Animal Science, vol. 82, no. 4, pp. 501-507, 2006.

[33] S. Q. Wu and M. L. Mei, "Study on pollination characteristic of Radix astragali," Journal of Anhui Agricultural Sciences, vol. 36, no. 21, pp. 9184-9303, 2008.

[34] M. M. Bradford, "A rapid and sensitive method for the quantitation of microgram quantities of protein utilizing the principle of protein dye binding," Analytical Biochemistry, vol. 72, no. 1-2, pp. 248-254, 1976.

[35] A. Summerfield, S. M. Knötig, and K. C. McCullough, "Lymphocyte apoptosis during classical swine fever: implication of activation-induced cell death," Journal of Virology, vol. 72, no. 3, pp. 1853-1861, 1998.

[36] H. Houe, "Epidemiological features and economical importance of bovine virus diarrhoea virus (BVDV) infections," Veterinary Microbiology, vol. 64, no. 2-3, pp. 89-107, 1999.

[37] T. Rumenapf, R. Stark, G. Meyers, and H.-J. Thiel, "Structural proteins of hog cholera virus expressed by vaccinia virus: further characterization and induction of protective immunity," Journal of Virology, vol. 65, no. 2, pp. 589-597, 1991.

[38] R. Schneider, G. Unger, R. Stark, E. Schneider-Scherzer, and H.J. Thiel, "Identification of a structural glycoprotein of an RNA virus as a ribonuclease," Science, vol. 261, no. 5125, pp. 1169-1171, 1993.

[39] Y. G. Gao, F. Y. Li, H. Yang, R. Du, and P. Zang, "Analysis on BVDV gene of E0 protein's character in Chinese sika deer," Journal of Biology, vol. 27, no. 5, pp. 1-3, 2010.

[40] M. Hernández, J. L. Cabrera-Ponce, G. Fragoso et al., "A new highly effective anticysticercosis vaccine expressed in transgenic papaya," Vaccine, vol. 25, no. 21, pp. 4252-4260, 2007. 


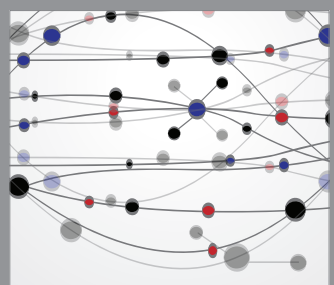

The Scientific World Journal
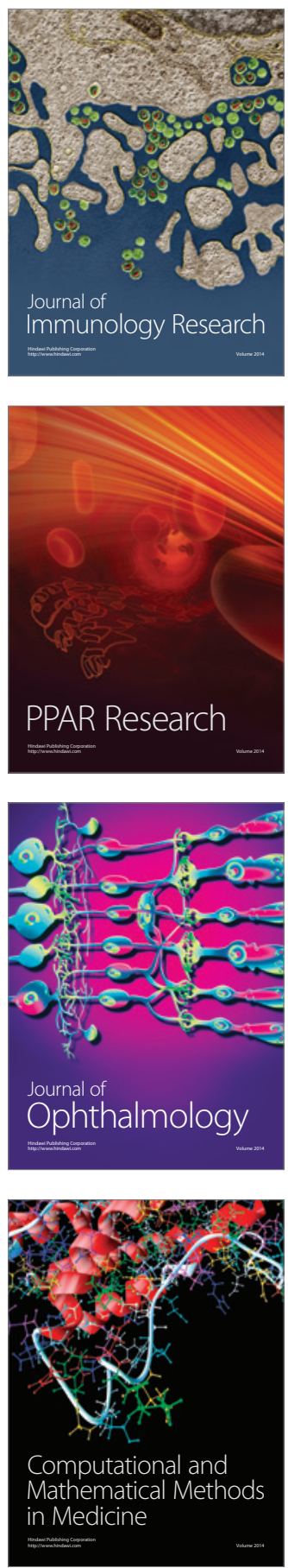

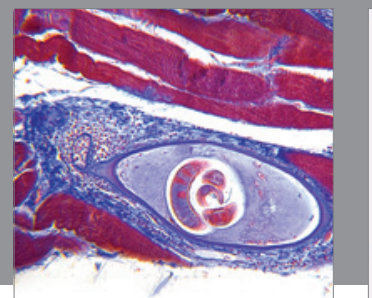

Gastroenterology

Research and Practice
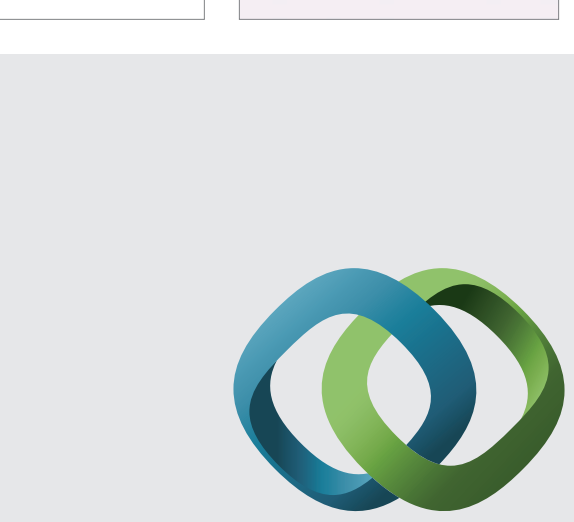

\section{Hindawi}

Submit your manuscripts at

http://www.hindawi.com
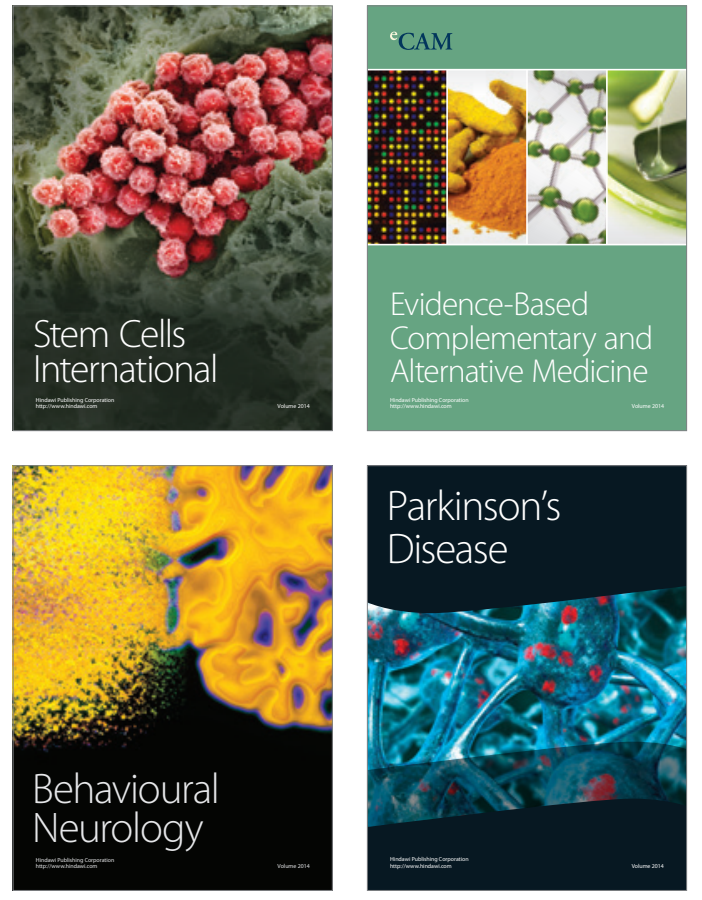
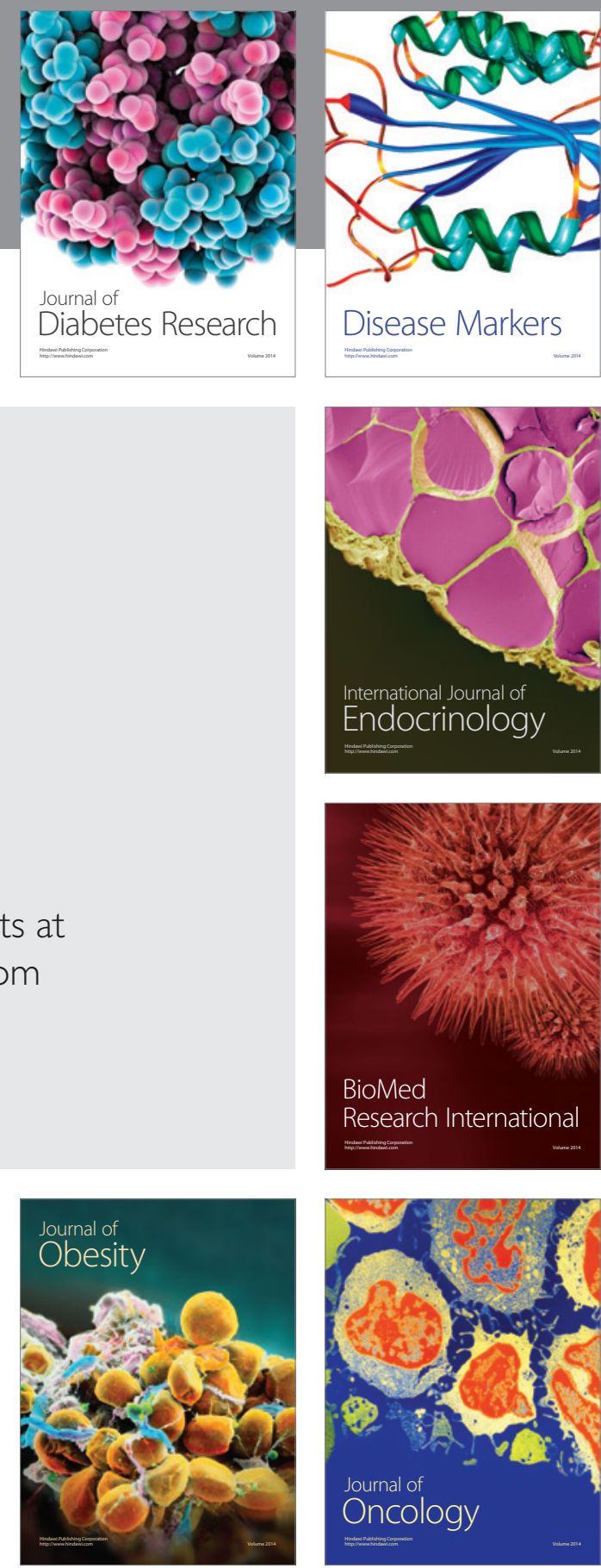

Disease Markers
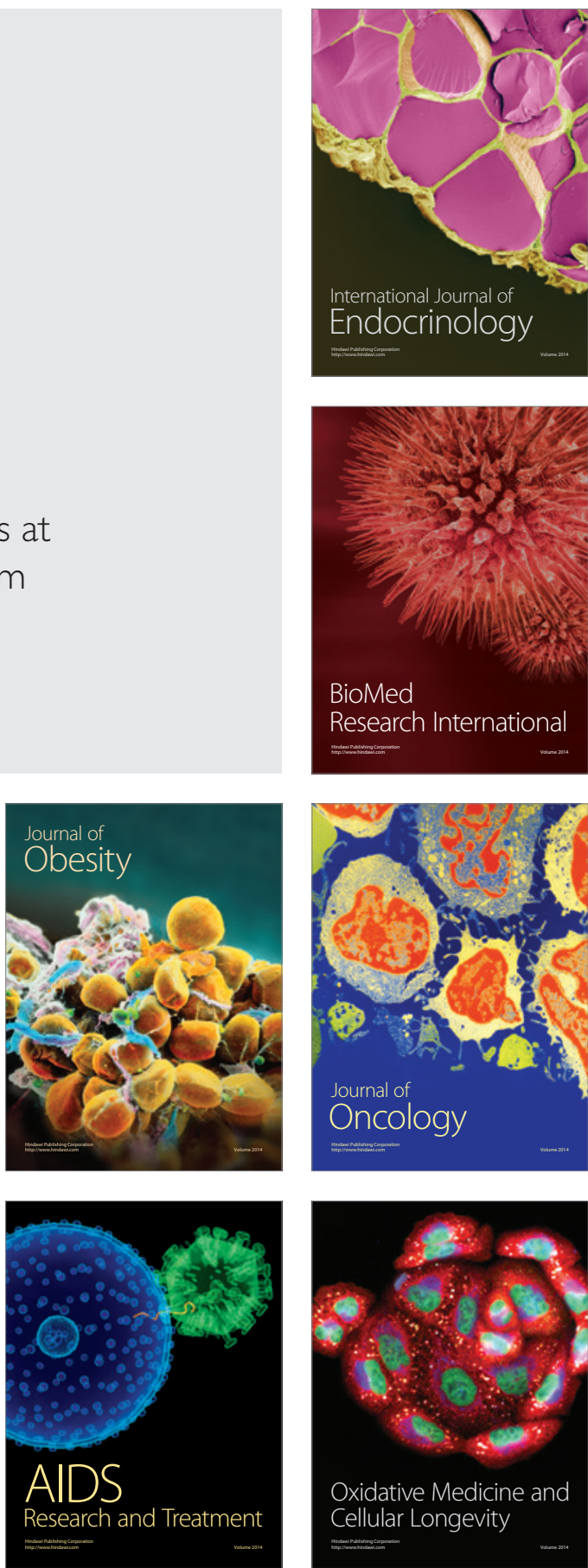